\title{
ARAC Dispersion Modeling Support for January-March 1995 Vandenberg AFB Launches
}

\author{
Prepared for: \\ Lt. Col Albert E. Sisk, Chief \\ Operations Tests \& Evaluation Branch, HQ AFSCP/DOTO
}

Ronald L. Baskett

John C. Pace

Regional Atmospheric Sciences Division

Lawrence Livermore National Laboratory

May 1995

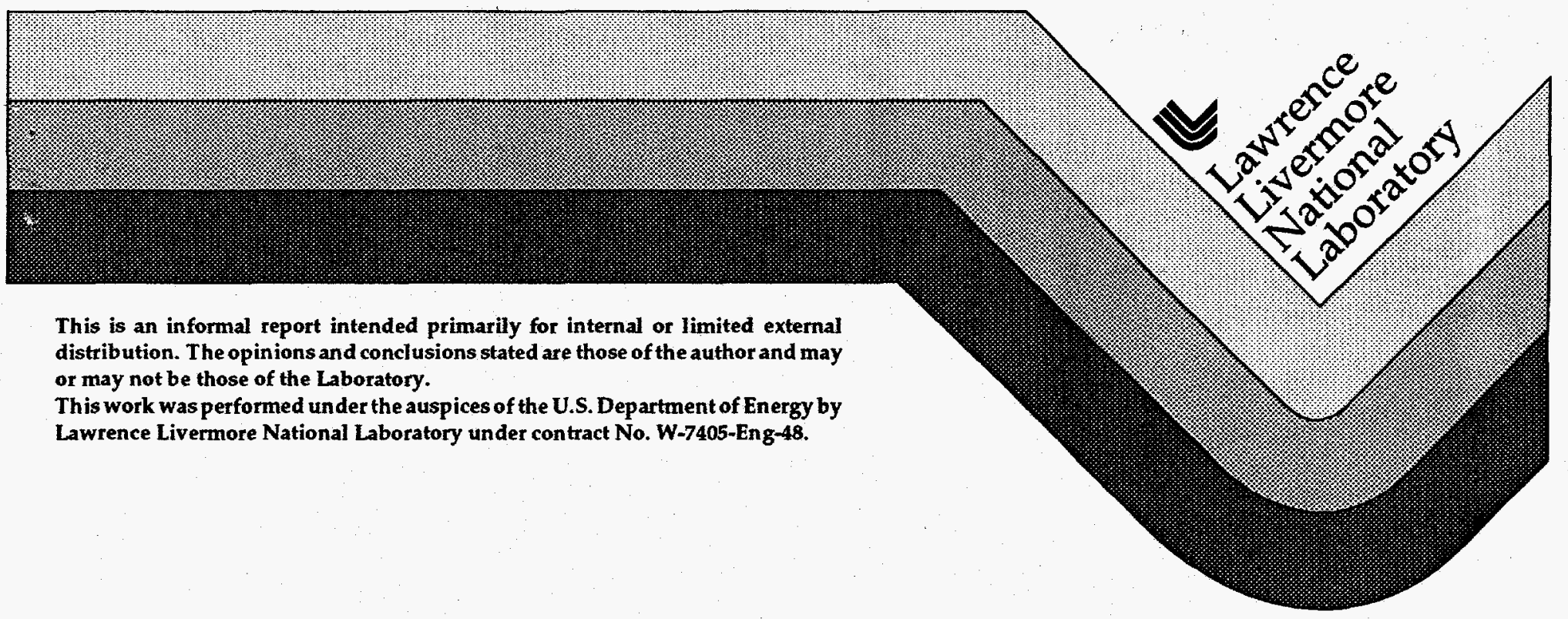




\section{DISCLAIMER}

This document was prepared as an account of work sponsored by an agency of the United States Government. Neither the United States Government nor the University of California nor any of their employees, makes any warranty, express or implied, or assumes any legal liability or responsibility for the accuracy, completeness, or usefulness of any information, apparatus, product, or process disclosed, or represents that its use would not infringe privately owned rights. Reference herein to any specific commercial product, process, or service by trade name, trademark, manufacturer, or otherwise, does not necessarily constitute or imply its endorsement, recommendation, or favoring by the United States Government or the University of California. The views and opinions of authors expressed herein do not necessarily state or reflect those of the United States Government or the University of California, and shall not be used for advertising or product endorsement purposes.

This report has been reproduced directly from the best available copy.

Available to DOE and DOE contractors from the Office of Scientific and Technical Information

P.O. Box 62, Oak Ridge, TN 37831

Prices available from (615) 576-8401, FTS 626-8401

Available to the public from the National Technical Information Service

U.S. Department of Commerce 5285 Port Royal Rd.

Springfield, VA 22161 


\section{DISCLAIMER}

Portions of this document may be illegible in electronic image products. Images are produced from the best available original document. 


\section{ARAC Dispersion Modeling Support for January-March 1995 Vandenberg AFB Launches}

\section{BACKGROUND}

The Glory Trip (GT) 17-PA Peacekeeper launch originally scheduled at Vandenberg Air Force Base (VAFB) between 15 and 20 November 1994 was cancelled based on modeled toxic exhaust cloud calculations. The Missile Flight Control Branch, 30th Space Wing Safety Office (30 SW/SEY), made several successive "No Go" decisions using Version 7.05 Rocket Exhaust Effluent Dispersion Model (REEDM) with forecasted meteorological conditions. REEDM runs made from T-14 hours to T-30 minutes predicted that ground-level concentrations of hydrogen chloride $(\mathrm{HCl})$ gas from the catastrophic abort case would exceed $5 \mathrm{ppm}$, the "instantaneous" ambient air concentration "Tier 2" limit at that time, modeled as a peak 1-minute cloud centerline concentration. Depending on the forecasted wind direction and speed at launch time, this limit was predicted to be exceeded sometimes at Base Housing, approximately $10 \mathrm{~km}$ southeast of the launch, and during other launch windows at the town of Casmalia, about $5 \mathrm{~km}$ east-southeast.

In late December 1994, the LLNL Atmospheric Release Advisory Capability (ARAC) program modeled the aborted November 1994 Peacekeeper launch and compared its results with REEDM. This initial comparison showed that the ARAC model predicted values about 1/3 as large as REEDM for the limiting case at Base Housing. Subsequently ARAC was asked to provide real-time modeling support to $30 \mathrm{SW} / \mathrm{SEY}$ during the rescheduled Peacekeeper GT 17-PA launch in January 1995 and two Minuteman launches in February and March. This report first briefly discusses the model differences and then summarizes the results of the three supported launches.

\section{EXPOSURE GUIDELINES FOR LAUNCHES}

Two cases--the nominal or normal launch and the catastrophic abort case-are modeled for each successive forecasted sounding between T-14 hours to T-30 minutes. Table 1 lists the exposure guidelines used to determine if the public health would be at risk for each of the two launch cases. Because exposure to $\mathrm{HCl}$ is concentration dependent, the guidelines are interpreted as instantaneous ceiling values. This was modeled as a 1-minute value before 30 December 1994 and changed to a 1second peak after the HQ AFSPC/SG memo on that date from Col. Machado.

TABLE 1. Launch Exposure Guidelines for $\mathrm{HCl}$ at VAFB

\begin{tabular}{|l|l|l|}
\hline GUIDELINE & BEFORE 30 DEC 1994 & AFTER 30 DEC 1994 \\
\hline $\begin{array}{l}\text { Tier } 2 \text { - } \\
\text { Cat. Abort }\end{array}$ & $5 \mathrm{ppm}$ for 1 minute & $10 \mathrm{ppm}$ for 1 second \\
\hline $\begin{array}{l}\text { Tier } 3 \text { - } \\
\text { Nominal }\end{array}$ & $1 \mathrm{ppm}$ for 1 minute & $1 \mathrm{ppm}$ for 1 second \\
\hline
\end{tabular}




\section{MODEL INPUTS AND PLUME RISE}

For both dispersion models, the primary inputs are source term and meteorological data. ACTA, Inc. provided the source rate $(\mathrm{HCl}$ in $\mathrm{g} / \mathrm{s}$ as a fraction of the missile fuel) and heat exhaust based on TRW data. A rawinsonde sounding (values of wind speed, wind direction, temperature and pressure with height) which has been forecasted for launch time is the primary meteorological input into the models. The mixing height is determined from the sounding vertical temperature profile.

The nominal rocket exhaust cloud is divided into several cylindrical volume sources at levels above ground. During the plume rise calculation each cylinder is transported by the mean wind speed and direction in each layer as determined from a rawinsonde sounding. The catastrophic abort case involves burning rocket fuel spread over an area on the ground. The emissions are put into a single ground-based spherical cloud initially, the radius of which is set by missile type. For every launch we studied, the catastrosphic abort case always produced concentrations closer to its corresponding Tier 2 exposure limit, and therefore was the limiting case.

REEDM uses a modified Briggs plume-rise code to calculate the final plume rise from the buoyant rocket exhaust cloud segments up to $3 \mathrm{~km}$. ARAC uses the standard Briggs plume-rise code, but we adjusted the heat content so that the final rise closely matched the value produced by REEDM for each case. As shown in Figure 1, ARAC used 9 source elements for the nominal cloud up to $1.5 \mathrm{~km}$. (Segments above $1.5 \mathrm{~km}$ were found to not contribute to ground-level concentrations within $20 \mathrm{~km}$ of the launch and therefore were not included.) Emissions from the propellent burn case were input into a single ground-level cloud for the catastrophic abort case.

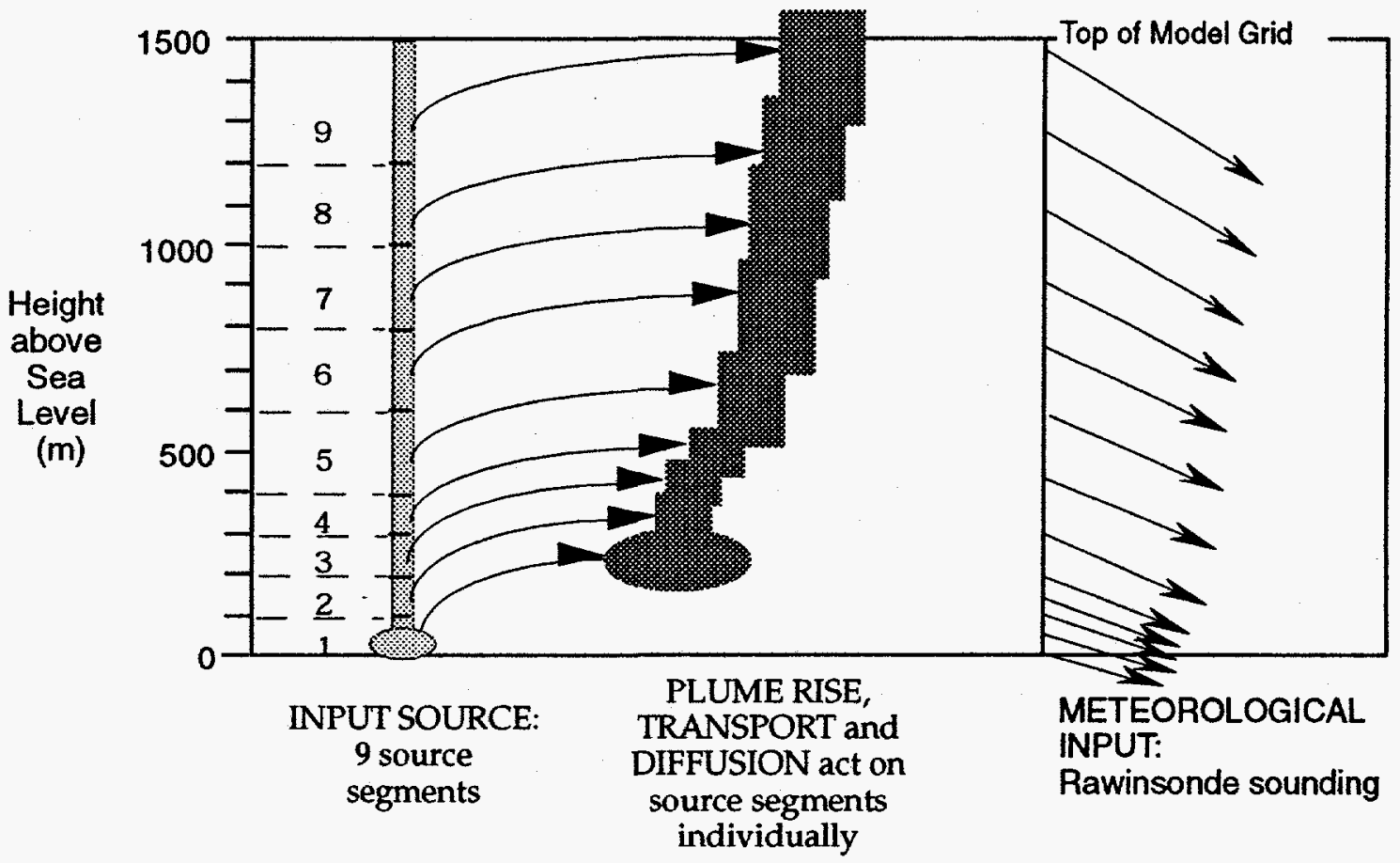

Figure 1. ARAC model simulation of plume rise from nominal launch 


\section{REEDM MODEL STRUCTURE}

REEDM is a steady-state Gaussian dispersion model developed over the last decade under contract to NASA and USAF specifically to simulate dispersion of rocket exhaust. Figure 2 illustrates the basic structure of the model. REEDM uses a single wind speed and direction at the mean boundary layer height (half way up to the mixing height) to transport the exhaust cloud segments after they have achieved final plume rise. Dispersion in the crosswind and vertical directions is computed using a normal distribution adjusted for atmospheric stability and downwind distance. Maximum concentrations occur along the cloud centerline.

The nominal cloud rise model calculation has been compared with several photographic datasets. There have been no comparisons with data for the catastrophic abort cloud rise. While REEDM has Gaussian structure common to many regulatory models, its dispersion calculations have not been evaluated against tracer measurements.

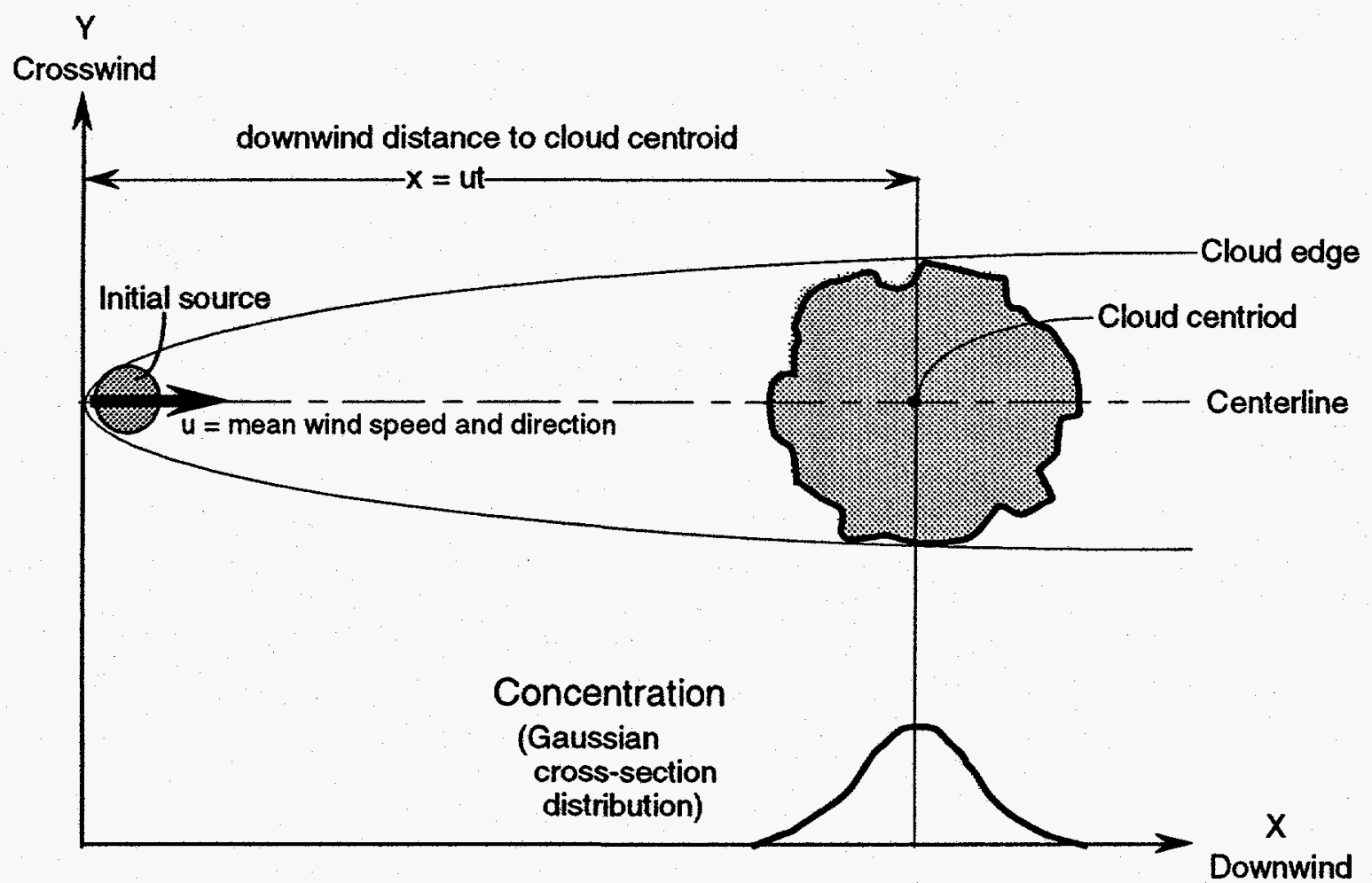

Figure 2. Top view of the REEDM Gaussian plume modeling structure

\section{ARAC MODEL STRUCTURE}

Figure 3 illustrates the ARAC model run stream which begins with the interpolation of meteorological inputs over a 3-D grid composed of $50 \times 50 \times 30$ grid cells (MEDIC code). Terrain is then injected into the bottom of the model domain and a mass-consistent wind field adjustment is made by MATHEW (Mass-Adjusted ThreeDimensional Wind field). The wind vectors that transport the cloud are modified 
depending on the terrain influence, and vertical velocities are created according to the atmospheric stability. While time-dependent plume-rise calculations are being made, the Atmospheric Dispersion by Particle-in-Cell (ADPIC) code computes the transport and dispersion of each source segment using thousands of marker particles, each of which represents a fraction of the total mass released. Dispersion rates are computed locally depending on wind speed and atmospheric turbulence conditions. The cloud is diffused according to the local 3-D diffusivity and the cloud's concentration gradient. Finally air concentrations of the material are mapped at or near ground level using specified contour values. 


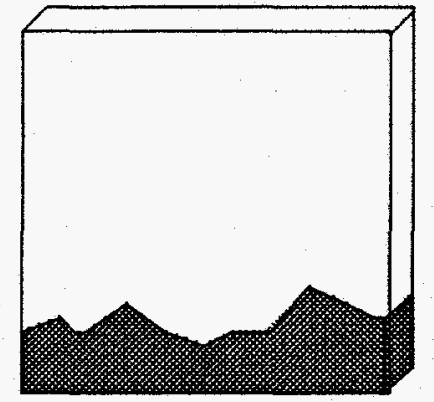

TOPOG

Creates underlying topographic grid

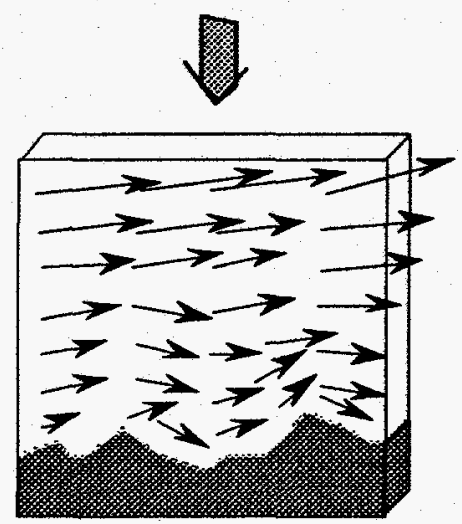

MATHEW

Adjusts winds to be mass consistent

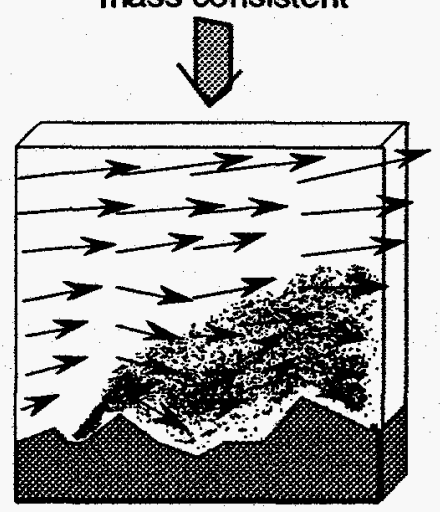

ADPIC

Advects and diffuses sources over grid using the particle-in-cell method

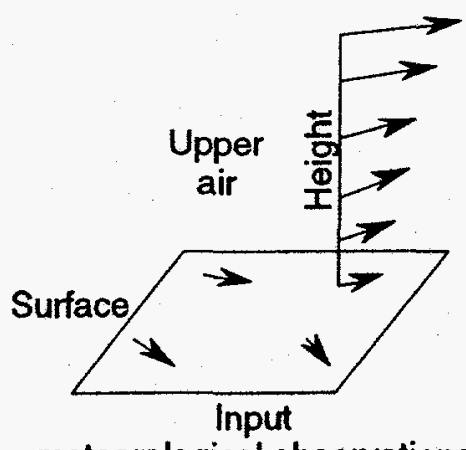

meteorological observations

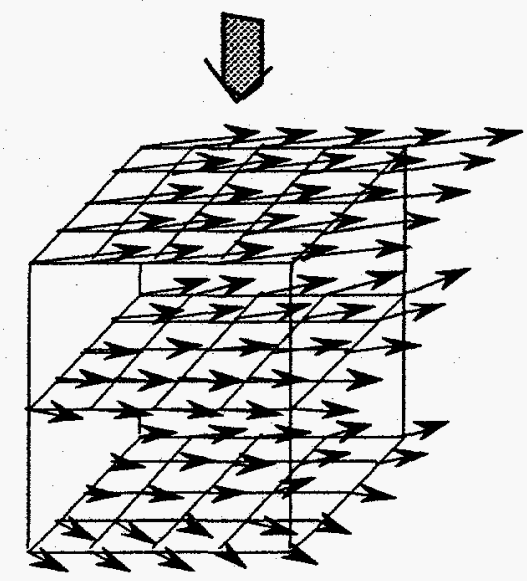

MEDIC

Interpolates observations

to 3-D grid using $1 / r^{2}$ weighting

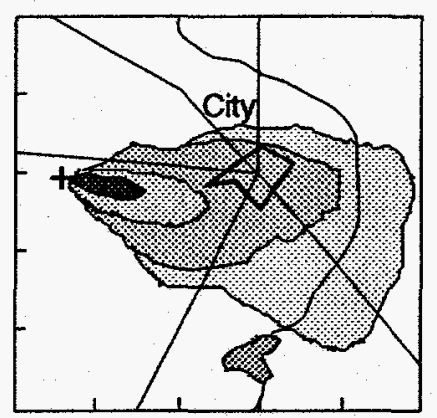

PLOT CONTOUR

Creates isopleth maps showing the extent of the hazard

Figure 3. ARAC model run stream

The ARAC numerical modeling system is generalized to treat complex flows in a variety of settings and has been evaluated against tracer data for over a dozen releases in many different settings over the last two decades (Sullivan, 1993). In the majority of these studies, computed concentrations were within a factor of 2 of measured values which were averaged over 10-60 minutes. While the model can calculate either instantaneous or averaged air concentrations, we have greater confidence in 
concentrations averaged over 5 minutes or longer. Maximum concentrations for shorter averaging times (e.g., $1 \mathrm{~min}$ to $1 \mathrm{sec}$ ) are subject to large variations and are difficult to model with any confidence.

Table 2 summarizes the differences that could be expected between the analytical Gaussian REEDM and the numerical particle-in-cell ARAC models. Operational REEDM calculations include uncertainty factors for model inputs (source data and meteorological forecast conditions) as well as uncertainty within the model itself. The ARAC model does not use uncertainty factors, but should reduce the uncertainty in the dispersion calculation. The net result from including wind shear, terrain and ground deposition is that the ARAC codes will produce lower ground-level air concentrations, except where an elevated cloud impacts elevated terrain.

TABLE 2. Differences between REEDM and ARAC models for several key uncertainty factors

\begin{tabular}{|c|c|c|c|}
\hline FACTOR & REEDM & ARAC & DIFFERENCE \\
\hline 1. Source rate & TRW test data & Same & None \\
\hline $\begin{array}{l}\text { 2. Cloud size and } \\
\text { rise }\end{array}$ & $\begin{array}{l}\text { Initialized with } \\
\text { calibrated stabilized } \\
\text { cloud rise model }\end{array}$ & $\begin{array}{l}\text { Uses time- } \\
\text { dependent cloud rise } \\
\text { with final height } \\
\text { matching REEDM }\end{array}$ & $\begin{array}{l}\text { ARAC model } \\
\text { provides detail of } \\
\text { dispersion near } \\
\text { source }\end{array}$ \\
\hline $\begin{array}{l}\text { 3. Dispersion } \\
\text { coefficients }\end{array}$ & $\begin{array}{l}\text { Gaussian model } \\
\text { values yet to be } \\
\text { validated }\end{array}$ & $\begin{array}{l}\text { Numerical model } \\
\text { validated with } 12 \\
\text { major tracer studies }\end{array}$ & $\begin{array}{l}\text { ARAC has known } \\
\text { total error (factor of } \\
2 \text { for }>50 \% \text { of time) }\end{array}$ \\
\hline $\begin{array}{l}\text { 4. Downwind 3-D } \\
\text { wind shear and } \\
\text { terrain effects }\end{array}$ & $\begin{array}{l}\text { Not included after } \\
\text { cloud rise }\end{array}$ & Included & $\begin{array}{l}\text { ARAC model } \\
\text { should produce } \\
\text { lower air } \\
\text { concentrations }\end{array}$ \\
\hline $\begin{array}{l}\text { 5. Reflection at } \\
\text { inversion and } \\
\text { ground }\end{array}$ & $\begin{array}{l}\text { Perfect reflection at } \\
\text { both inversion and } \\
\text { ground }\end{array}$ & $\begin{array}{l}\text { Variable reflection } \\
\text { at inversion; } \\
\text { deposition at ground }\end{array}$ & $\begin{array}{l}\text { ARAC model will } \\
\text { produce lower air } \\
\text { concentrations }\end{array}$ \\
\hline $\begin{array}{l}\text { 6. Error in } \\
\text { forecasted } \\
\text { sounding }\end{array}$ & $\begin{array}{l}\text { A single forecasted } \\
\text { sounding is input }\end{array}$ & $\begin{array}{l}\text { Same (However, } \\
\text { ARAC could use } \\
\text { multiple inputs) }\end{array}$ & $\begin{array}{l}\text { Directional errors in } \\
\text { a single forecast } \\
\text { sounding would be } \\
\text { the same }\end{array}$ \\
\hline
\end{tabular}

\section{COMPARISON OF MODEL RUNS}

Table 3 compares ARAC and REEDM model results for the catastrophic abort case from 2 preparation studies and 3 launches. We compared the ground-level cloud centerline values either at downwind distances of the maximum air concentration or at the population area of concern during the launch.

The initial comparison of the cancelled PK launch on 18 November 1994 showed that the ARAC concentration (converted to a 1-minute average) produced a $7 \mathrm{ppm}$, which was about $1 / 3$ of REEDM, but still greater than the $5 \mathrm{ppm}$ Tier 2 limit at the time. 
Subsequently, ARAC and REEDM were run using several qhistorical soundings representing climatological cases for the January launch window. Each of these runs compared 5-minute averages, before the maxima were converted to 1-second peak concentrations by each model for the Go/No-Go decision. The historical comparisons show that, when population centers ("pop centers") were involved, the ARAC model indicated a "Go" for launch 12 of the 13 cases while REEDM produced only 2 "Go's".

Table 3. Comparison of launch decisions using REEDM and ARAC models for North Base catastrophic abort cases

\begin{tabular}{|c|c|c|c|c|}
\hline $\begin{array}{c}\text { DATE } \\
\text { OF RUNS }\end{array}$ & $\begin{array}{l}\text { MODELED } \\
\text { LAUNCH }\end{array}$ & $\begin{array}{l}\text { COMPARED } \\
\text { LOCATION }\end{array}$ & $\begin{array}{c}\text { DECISION } \\
\text { WITH } \\
\text { REEDM } \\
\end{array}$ & $\begin{array}{c}\text { DECISION } \\
\text { WITH ARAC }\end{array}$ \\
\hline $\begin{array}{c}\text { 26-29 Dec } \\
1994\end{array}$ & $\begin{array}{c}\text { Analysis of } \\
\text { aborted PK-17A } \\
\text { on } 18 \text { Nov } 94\end{array}$ & $\begin{array}{c}\text { Base Housing } \\
\text { Casmalia }\end{array}$ & $\begin{array}{l}\text { No Go } \\
\text { No Go }\end{array}$ & $\begin{array}{c}\text { No Go } \\
\text { Go }\end{array}$ \\
\hline $\begin{array}{c}12-15 \text { Jan } \\
1995\end{array}$ & $\begin{array}{l}\text { PK case studies } \\
\text { for the } \\
\text { January window } \\
\text { from historical } \\
\text { soundings }\end{array}$ & $\begin{array}{l}\text { To the north } \\
\text { Base Housing } \\
\text { To the south }\end{array}$ & $\begin{array}{c}6 \text { No Go } \\
2 \text { No Go/ } 2 \text { Go } \\
3 \text { No Go }\end{array}$ & $\begin{array}{c}6 \mathrm{Go} \\
4 \mathrm{Go} \\
1 \mathrm{No} \mathrm{Go} / 2 \mathrm{Go}\end{array}$ \\
\hline 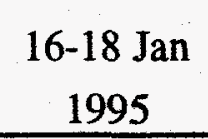 & $\begin{array}{l}\text { PK-17A } \\
\text { launch }\end{array}$ & Offshore & $\begin{array}{c}\text { Go } \\
\text { (no pop center) }\end{array}$ & Go \\
\hline $\begin{array}{r}1 \mathrm{Feb} \\
1995 \\
\end{array}$ & $\begin{array}{l}\text { MM III } \\
\text { launch }\end{array}$ & $\begin{array}{l}\text { Southward } \\
\text { (offshore) }\end{array}$ & $\begin{array}{c}\text { Go } \\
\text { (no pop center) }\end{array}$ & Go \\
\hline $\begin{array}{c}\text { 15-17 Mar } \\
1995\end{array}$ & $\begin{array}{l}\text { MM III } \\
\text { launch }\end{array}$ & $\begin{array}{c}\begin{array}{c}\text { Southward } \\
\text { (alongshore) }\end{array} \\
\text { Rotated to } \\
\text { Base Housing }\end{array}$ & $\begin{array}{c}\text { Go } \\
\text { (no pop center) } \\
\text { No Go }\end{array}$ & $\begin{array}{c}\text { Go } \\
\text { No Go }\end{array}$ \\
\hline
\end{tabular}

Fortunately during the 3 launches in January, February, and March, the winds directed the clouds away from any population centers. However, both models would have produced concentrations above the $10 \mathrm{ppm} \mathrm{1-second} \mathrm{limit} \mathrm{if} \mathrm{the} \mathrm{wind} \mathrm{direction} \mathrm{was}$ rotated over Base Housing for the 17 March MM III launch. It is likely that both models will show that any nighttime launch from the North Base area will exceed the Tier 2 
criteria anytime the wind blows towards Base Housing with little directional shear in the vertical.

Table 4 summarizes the general quantative differences between the models based on the comparison runs to date at the nearest population center $(5-10 \mathrm{~km})$ in each downwind sector. When no significant terrain or wind shears are involved, the REEDM and ARAC models produce about the same concentrations (within a factor of 2). When terrain blocks the cloud to the north or east, the ARAC model shows about a factor of 4 to 5 less concentration at the population centers downwind of the blocking. When significant changes in wind direction with height occur, the ARAC model calculates up to a factor of 4 less than REEDM. However, because each individual ratio depends strongly on the unique combination of meteorological and topographic conditions, that ratio cannot be generalized for a specific location.

Table 4. Ratios of REEDM to ARAC model maxima at population centers

\begin{tabular}{|l|l|c|}
\hline \multicolumn{1}{|c|}{$\begin{array}{c}\text { MODELED } \\
\text { CONDITION }\end{array}$} & $\begin{array}{c}\text { DIRECTION } \\
\text { (and Population Center) }\end{array}$ & $\begin{array}{c}\text { TYPICAL } \\
\text { RATIO OF } \\
\text { REEDM to ARAC }\end{array}$ \\
\hline \hline $\begin{array}{l}\text { Flat or rolling terrain and } \\
\text { steady winds }\end{array}$ & $\begin{array}{l}\text { Offshore, southward or } \\
\text { towards base housing }\end{array}$ & $1-2$ \\
\hline Terrain-blocked locations & $\begin{array}{l}\text { To the east or northeast } \\
\text { (Casmalia, Guadalupe) } \\
\text { To the north (6 Trailers) }\end{array}$ & $4-5$ \\
\hline Wind shear & Any direction & up to 4 \\
\hline
\end{tabular}

\section{CONCLUSIONS}

The catastrophic abort case, when compared to the current Tier $2(10 \mathrm{ppm} \mathrm{HCl})$ concentration interim guideline, is the limiting case for North Base missile launches at Vandenberg AFB. About 2 dozen model runs were made to compare the maximum centerline concentrations of the ARAC numerical model to REEDM Gaussian model for nighttime launches. When wind shear or terrain effects are involved, the ARAC 3-D calculation can produce up to 5 times smaller concentrations than REEDM at the nearest downwind population center $5-10 \mathrm{~km}$ downwind of the launch. The ARAC model would indicate "Go" to launch for the majority of these cases when the REEDM would not. However, for strong, steady winds toward Base Housing, it is likely that both models would concur that the current interim exposure limit would be exceeded.

\section{REFERENCE}


Sullivan, T. S, J. S. Ellis, C. S. Foster, K. T. Foster, R. L. Baskett, J. S. Nasstrom, W. W.Schalk. 1993: Atmospheric Release Advisory Capability: Real-time modeling of airborne hazardous materials, Bull. Amer. Meteor. Soc. 74: 2343-2361. 